\title{
Normalization of Cognitive Thinking by Healthy Lifestyle
}

\author{
E.G.Bryndin, I.E.Bryndina \\ Technological platform "FUTURE MEDICINE", Russia, \\ Research center "ESTESTVOINFORMATIKA", Novosibirsk
}

\begin{abstract}
In the conditions of the increasing information loads of consciousness of the person, actual is a problem of normalization of cognitive thinking. Effectively it is promoted by comprehensive knowledge, individual development and improvement of a healthy lifestyle.
\end{abstract}

Keywords: cognitive thinking, mental energy, healthy lifestyle.

The thinking is process of mentality. Mentality (from other - Greek $\psi \bar{v} \chi 1 \kappa o ́ \varsigma-$ sincere, vital) - set of sincere processes and the phenomena (feeling, perception, emotions, thinking, etc.); the form of active display by the subject of objective reality which is arising in the course of interaction of highorganized living beings with the outside world and carrying out regulatory function in their behavior (activity). Mental processes are realized by mental energy. Under the influence of mental energy there is a development of the person. Mental energy gets into all cages. The biochemical carrier of mental energy are structural components of a cover of nervous fibers of the lipidic nature. Quality of mental energy of a brain depends on purity of thoughts. Pure the consciousness produces creative mental energy, differently destructive mental energy of disorder of a brain is produced. Destructive vibrations of mental energy appear at the person as a result of action of his negative emotions.

Creative clever mental energy collects in the course of training and new activity. Places of accumulation of mental energy are the nervous ways activated in the course of brain activity. Mental clever energy, influencing through a wave genome the genetic mechanism, forms functioning of a brain in the course of creative activity.

Quality of mental energy is generated by values. The number of value which is appropriated to the relation or kind of activity determines the level of intensity of energy. This compliance shows that the consciousness is valuable dimension of mental energy. Mental energy of a brain crystallizes activity of consciousness.

As structure of typical individual consciousness the structure of semantic space of activity given in concrete forms of unity, integrity of the highest regulatory conditions of the central nervous system providing this activity serves. Respectively, the content of concrete individual consciousness are the meanings of system work, active in the current activity of the specific individual and in the specified forms of integrity of his central nervous system. That is there is a compliance between meanings of system activity and contents of individual consciousness. Compliance, is mediated by the biological and intellectual factors defining this activity.

Accumulation of creative mental energy a brain is its reserve and defines relevance of normalization of its accumulation and use in the course of cognitive thinking. Research, identification and application of a healthy lifestyle to normalization of cognitive thinking defines novelty of approach in the conditions of the increasing information loads of consciousness of the person.

Source of mental energy is the brain together with channels of perception of information of a different look (modality) - analyzers. Each analyzer, as we know, is adapted for reflection of concrete energy: visual and acoustical - electromagnetic (at the heart of light and a sound electromagnetic oscillations lie), olfactory and flavoring - chemical; skin and kinestetichesky, the supplying information on temperature, external and internal pressure, on the movements of own body, - mechanical and thermal; vestibular, reflecting our situation in space, - gravitational. Having apprehended influence of energy of this or that look, a brain then makes an assessment of the arrived information: compares with the "samples" which are stored in memory defines degree of usefulness or danger to life, reveals degree of appeal to the identity of the owner etc. After that, as we know, there is a reciprocal reaction, for example, by means of words, emotions, decision-making or actions. 
Here that N.P.Bekhtereva (The Russian authority on brain area) speaks: - Work of a brain provides difficult mental activity! Mental energy knows everything about tens of thousands of sites participating in mental activity. And they in turn know of it, only. The brain owns the tool which as required gives opportunity of urgent transfer of unlimited volume of information.

The live brain represents the device by means of which there is a transformation of the different types of energy influencing the person to mental energy (energy ideal) and back - mental energy (energy ideal) in other types of energy.

Energy allocated images, thoughts, requirements, abilities, emotions, feelings, knowledge, installations, moods, habits, desires, motives, properties of character, - all these and other manifestations of mentality are carriers ideal. The matter is that they are sated with information, which is a component of mental energy. Information constantly works, is in process of transformation and that is the extremely important, exists in very squeezed form. The brain of each person stores a huge number of information ready at any time to declare itself. Information filled our consciousness.

It is necessary to watch purity of thoughts and all life. Spiritual purity - is the rainbow of mental energy containing all colors. The person constantly accumulates and shows mental energy communicative spiritually semantic values and actions. Mental energy realizes, first, spiritually thought process by communicative semantic synthesis, secondly, spiritually semantic speechacoustical dialogue, thirdly, intelligent physical actions. Mental energy of thought influences people, water, flowers and other subjects. Mental energy accumulates on subjects, influencing them. It unites the external and internal environment of activity of the person. Therefore it is necessary to be able to operate mental energy. It is carefully necessary to treat mental energy. It is necessary for assimilation of methods of experience with mental energy to be able to own the thinking. Uniform distribution and use by net positive mental energy it is possible to normalize cognitive thinking. Uniform distribution and use of net positive mental energy and normalization of cognitive thinking are carried out by knowledge, development and improvement of a healthy lifestyle.

Transition to a healthy lifestyle is carried out in four stages.

\section{Stage1. Formation of THE Clean inTERnAl ENVIRONMENT}

The pure internal environment is one of necessary conditions of a wave resonance of cages. The clean internal environment is formed by useful habits:

1. At the spiritual level: formation pure thoughts and desires.

2. Development of an ethical lexicon of communication.

3. At the power level communication with clean nature: absorption by enzymes of light energy, vibrations of flora, equilibration of mentality by tranquillity of the nature, an emotional positive spirit from beauty of the nature, air, solar and water physical exercises, inhalation of clean air, coordination of the internal environment of an organism with the natural.

Improvement of health in ecological pure environment develops nature needs and a habit to communicate with the nature. Nature need and habit to communicate with the nature normalize genetically internal environment of an organism through a wave genome.

4. Maintenance of the internal environment of an organism by release from negative energy: water procedures in soul or a bathroom before the use of food, and also once a week in a bath.

Desire of improvement of health after stay in the adverse power environment and to keep it develops nature need and a habit to take a shower or a bathtub before the use of food and once a week to clean an organism in a bath steam room.

Nature need and a habit to take a shower or a bathtub before the use of food and once a week to clean an organism in a steam room of a bath relieve an organism of negative energy and supports pure the internal environment of an organism.

5. Preservation of the pure internal environment classical, sacred, harmonious music at the geneticswave level.

The desire to have and keep good health develops nature need and a habit to listen to harmonious music. Nature need and a habit to listen to harmonious music support genetically the pure internal environment of an organism through a wave genome at the power level. 
6. Development of alkaline food ( $80 \%$ of pure alkaline food and $20 \%$ of clean acid food) for normalization of acid-base balance of biological environments of an organism.

The desire to keep good health after acceptance of food develops nature need and a habit of alkaline food. Nature need and a habit of alkaline food by the rule to choose useful among tasty and tasty among the useful support acid-base balance of biological environments of an organism through a metabolism at the physiological level.

7. Normalization of acid-base balance through a water exchange at the physiological level by use the pure water.

Nature need and habit to use clear water support acid-base balance of biological environments of an organism through a cellular and intercellular water exchange.

8. Observance of hygiene for maintenance of the environmentally friendly internal environment of an organism.

Nature need and habit to observe hygiene support acid-base balance of biological environments of an organism clarification it from parasites and pollution.

9. Diagnostics of acid-base balance of biological environments of an organism.

Nature need and habit to diagnose acid-base balance of biological environments of an organism help to control it.

\section{Stage2. Development of improving Abilities for AChievement of a Healthy STATE}

Spiritual, mental and power purity are necessary conditions of a wave resonance of cages. The stage includes the following useful habits:

1. Spiritual actions, such as, reading spiritual literature, visit of spiritual actions, development of spiritual consciousness and spiritual and moral qualities, formation of spiritual bonds for achievement of a spiritual healthy state.

Development of abilities to make spiritual actions develops nature need and a habit to get rid from harmful passions, to gain a sound spirit and spiritual health.

2. Formation of just peace kind thoughts and desires for spiritual activity.

Nature need and habit to form just peace kind thoughts and desires conduct to spiritual activity and spiritual health.

3. Development of spiritual abilities of humility, forgiveness, mercy, formation of the peace kind relations in various social conditions and a family for spiritual activity.

Abilities of manifestation of humility, forgiveness, mercy, formation of the peace kind relations for equilibration of soul in various social conditions and a family develop nature need and a habit to be soul balanced and to have a sound spirit and spiritual health.

4. Manifestation of spiritual and moral qualities - good wills and blessings, mercy and justice for spiritual activity.

Manifestation of spiritual and moral qualities good wills and blessings, mercy and justice develop nature need and a habit to build the peace kind relations and forms a sound spirit and spiritual health.

5. Development of abilities of control of vital systems of an organism and its complete normal functioning by physical exercises: charging of a power system, physical culture of a tone of an organism and gymnastics of rhythms for achievement of a physical healthy state of an organism.

Ability of control of vital systems of an organism and its complete normal functioning develop needs of nature and a habit to support a healthy state of an organism.

6. Development of healthy food for maintenance of a physical healthy state of an organism.

Healthy food improves a healthy habit to support a physical healthy state of an organism.

7. Development of complex abilities of achievement of a healthy state on the basis of system of cellular self-restoration of an organism improvement of a qualitative condition of cages at the spiritual, power, physiological and anatomic levels. 
Ability of improvement of a qualitative condition of cages at the spiritual, power, physiological and anatomic levels on the basis of system of cellular self-restoration of an organism improves a healthy habit to support a complete healthy state of an organism.

8. Frequency and resonant diagnostics of a healthy state.

Development of a habit periodically to diagnose an organism helps to support a healthy state.

\section{Stage3. Acquisition of Skills Health of Saving for Preservation of a Healthy STATE}

It includes the following useful habits:

1. Development of rules of daily preservation of a healthy state.

Development of rules develops skills and a daily habit to keep a healthy state.

2. Equilibration of soul in social conditions by peace kind relations, doing good, evading it is evil, looking for the peace and aspiring to it for spiritual health of saving.

Abilities and skills of manifestation of humility, forgiveness, mercy and the peace kind relations counterbalance soul in various social conditions and develop a daily habit to be soul balanced to have a sound pirit and to support a spiritual healthy state.

3. Daily formation of physical healthy functioning of an organism at the beginning of day control of vital systems.

Skills of ensuring healthy functioning of an organism develop a daily habit of preservation of a healthy state.

4. Coordination with a daily natural cycle of activity in social, natural and house conditions for preservation of complete healthy functioning of an organism.

Skills of daily coordination of healthy activity with a daily natural cycle develop a daily habit of preservation of a healthy state in various social, natural and house conditions.

5. Complex daily preservation of a healthy state at the spiritual, power, physiological and anatomic levels in various house, natural and social conditions on the basis of system of cellular selfrestoration.

Skills of complex daily preservation of a healthy state at the spiritual, power, physiological and anatomic levels in various house, natural and social conditions on the basis of system of cellular selfrestoration develop a habit of preservation of a complete healthy state during every day.

6. Preservation of physical healthy functioning of an organism healthy food.

Skills of daily healthy food constantly support a healthy state.

7. Frequency and resonant diagnostics of a healthy state.

Weekly diagnoses an organism helps support a health.

\section{Stage4. Accumulation of Experience of a Healthy Lifestyle for Preservation OF A HEALThy STATE WiThIN A Year}

Accumulation of experience is carried out by skills health of saving in various house, social and natural seasonal conditions (in the spring, in the summer, in the fall and in the winter). Experience includes the following useful habits:

1. Seasonal preservation of balanced soul and ensuring complete healthy functioning of an organism in the summer, in the fall, in the winter, in the spring on the basis of system of cellular selfrestoration.

Experience of seasonal preservation of balanced soul and ensuring complete healthy functioning of an organism in the summer, in the fall, in the winter, in the spring on the basis of skills of daily preservation of a healthy state develops nature need and a habit to support a healthy state of an organism within a year.

2. Healthy seasonal food. 
Accumulation of experience of seasonal healthy food develops nature need and a habit to support a healthy state of an organism within a year.

3. Choice of seasonal natural clothes.

Accumulation of experience of a choice of seasonal natural clothes develops nature need and a habit to support a healthy condition of an organism within a year.

4. Accumulation of experience of complex coordination of social healthy activity with an annual natural cycle at the spiritual, power, physiological and anatomic levels in various house, natural and social conditions.

Accumulation of seasonal experience of complex coordination of social healthy activity with an annual natural cycle develops nature need and a habit to support a healthy condition of an organism within a year.

5. Accumulation of experience of formation of family tradition of a healthy lifestyle.

Accumulation of experience of formation of family tradition of a healthy lifestyle develops nature need and a habit to support a healthy condition of an organism within a year family members.

6. Accumulation of experience of formation of cultural public tradition of a healthy lifestyle.

Accumulation of experience of formation of cultural public tradition of a healthy lifestyle develops nature need and a habit to motivate citizens, to reach and support a healthy condition of an organism and to lead a healthy lifestyle within a year.

7. Accumulation of experience of periodic frequency and resonant diagnostics of a healthy state.

Experience accumulation periodically to diagnose an organism helps to support a healthy state within a year.

\section{SUMMARY}

Normalization of cognitive thinking of citizens by knowledge, development and improvement of a healthy lifestyle accumulates positive creative mental energy which will help mankind to pass to peaceful just healthy activity with the uniform global innovative diversified economy which isn't breaking ecology of the surrounding nature with completion of resources [1-11]. Positive creative mental energy will help the person and mankind to live in consent with the nature and to keep the general house-earth in clean.

\section{REFERENCES}

[1] Bekhtereva N. Magiya of a brain and life labyrinths. - M.: ACT; SPb.: Owl, 2007. - 349 p.

[2] Bryndin E. G. Ecological Drug-Free Health Care [Ekologicheskoe nemedikamentoznoe zdravookhranenie]. Mezhdunarodnyy kongress "Progress $v$ fundamentalnykh $i$ prikladnykh naukakh dlya zdorovya cheloveka" (International Multidisciplinary Congress "Progress in Fundamental and Applied Sciences for Human Health"). Sudak, 2004, pp. 81 - 82.

[3] Bryndin E. G., Bryndina I. E. Healthy Man and Society Bases [Osnovy zdorovogo cheloveka $i$ obschestva]. Tomsk, TPU, 2011, 302 p.

[4] Bryndin E. G., Bryndina I. E. Healthy Longevity Bases [Osnovy zdorovogo dolgoletiya]. Germany, LAP Lambert Academic Publishing, 2012, 225 p.

[5] Bryndin E. G., Bryndina I. E. Healthy Life Style Syllabus for School Children [Programma po obucheniyu shkolnikov zdorovomu obrazu zhizni]. II Vserossiyskaya nauchno-prakticheskaya konferentsiya "Sozdanie integrirovannogo obrazovatelnogo prostranstva dlya razvitiya detskoy odarennosti: detskiy sad - shkola - universitet", Chast I: Pedagogika odarennosti (II AllRussian Scientific and Practical Conference "Creation of the Integrated Educational Space for Children's Endowments Development: Kindergarten - School - University", Part I, Pedagogy of Endowments). Tomsk, Tomskiy TsNTI, 2012, pp. $182-187$.

[6] Bryndin E. G., Bryndina I. E. Students Health Indicator Dynamics Increase Monitoring [Monitoring dinamiki povysheniya pokazateley zdorovya obuchayuschikhsya]. Mezhdunarodnaya konferentsiya "Sovremennye aspekty realizatsii FGOS i FGT (International Conference "Modern Aspects of Federal State Learning Standard and Federal State Requirements Realization”). Krasnoyarsk, KrasGMU, 2013, pp. 500 - 504. 
[7] Bryndin E. G., Bryndina I. E. How to Pass to the Healthy Life Style [Kak pereyti na zdorovyy obraz zhizni]. Tomsk, TPU, 2013, 288 p.

[8] Bryndin E. G., Bryndina I. E. Social Infrastructure of Forming Population's Healthy Life Style Management [Upravlenie sotsialnoy infrastrukturoy formirovaniya zdorovogo obraza zhizni naseleniya]. Mezhdunarodnyy nauchnyy simpozium "Obschestvo i nepreryvnoe blagopoluchie cheloveka" (International Scientific Symposium "Society and Continuous Prosperity of a Man"). Tomsk, TPU, 2014, pp. $102-106$.

[9] Bryndin E. G., Bryndina I. E. Formation of Worldview of Healthy Lifestyle at Young Generation [Formirovanie mirovozzreniya zdorovogo obraza zhizni u molodogo pokoleniya]. 2 Vserossiyskaya meditsinskaya nauchno-prakticheskaya konferentsiya "Razvitie Rossiyskogo zdravookhraneniya na sovremennom etape" (2 $2^{\text {nd }}$ All-Russian Medical Scientific Practical Conference "Development of Russian Health Protection at the Present Stage"). Moscow, Editus, 2014, pp. $177-183$.

[10] Evgeny Bryndin. Uniform economy of global wellbeing. Germany: LAP LAMBERT Academic Publishing. 2015. $105 \mathrm{c}$.

[11] E.G.Bryndin \& I.E.Bryndina. Natural-Science Aspects of Health. / Weber Medicine \& Clinical Case Reports.Vol. 1(1). 2015. pp. 134-137. URL: http://weberpub.org/wmccr/wmccr_122.pdf

[12] Evgeny Bryndin. Economic Aspect of Global Wellbeing. Journal "The European Proceedings of Social \& Behavioural Sciences". Volume VII. 2016.

[13] Е.Г. Брындин. К вечному бытию. Germany: LAP LAMBERT Academic Publishing. 2016. 152 c.

[14] E.G.Bryndin \& I.E.Bryndina. SANATORIUM TRANSITION OF THE POPULATION ON THE HEALTHY LIFESTYLE. Journal "The European Proceedings of Social \& Behavioural Sciences". Volume VII. 2016. 